\title{
Penerimaan Pengguna E-Wallet Menggunakan UTAUT 2 (Studi Kasus)
}

\author{
(User Acceptance of E-Wallet Using UTAUT 2 - A Case Study)
}

\author{
Muhammad Taufik Hidayat ${ }^{1}$, Qurrotul Aini ${ }^{2}$, Elvi Fetrina ${ }^{3}$
}

\begin{abstract}
Nowadays, e-wallet (electronic wallet) is used for non-cash transactions because of the ease and practicality of transactions offered by service providers in South Tangerang. However, the success of the server-based e-wallet that has been implemented is still unknown, and there are still problems in the form of loss of balance and failure to top up. One of determinants of the system to be successful is in terms of user acceptance perspective. The objective of this paper is to derive and investigate significant variables on the user acceptance of server-based ewallets in South Tangerang with the UTAUT 2 model and the addition of two variables, namely perceived trust and perceived risk. The study is conducted with a quantitative approach, questionnaires online with 33 questions, and demographic data analysis using IBM SPSS 25, as well as PLS-SEM analysis using SmartPLS 3.2.8. The results show that out of twelve proposed hypotheses, three hypotheses are declared insignificant and rejected because the path coefficient value and t-test of these hypotheses (performance expectancy, hedonic motivation, and price value) are less than 0.1 and 1.96. In contrast, nine others are declared significant and accepted.
\end{abstract}

Intisari-E-wallet (dompet elektronik) berbasis server saat ini banyak digunakan dalam transaksi bukan tunai untuk keleluasaan dan efisiensi dalam bisnis yang diberikan oleh pemberi servis di Tangerang Selatan. Namun, masih terjadi permasalahan hilangnya saldo dan gagalnya pengisian saldo serta belum diukurnya tingkat keberhasilan implementasi $e$-wallet berbasis server. Salah satu faktor penentu keberhasilan sistem yang diterapkan adalah dari sisi penerimaan penggunanya. Makalah ini bertujuan mendapatkan variabel yang signifikan terhadap penerimaan pengguna $e$-wallet berbasis server di Tangerang Selatan dengan model UTAUT 2 dan penambahan dua variabel, yaitu perceived trust dan perceived risk. Penelitian dilakukan dengan cara kuantitatif, distribusi kuesioner/angket secara online dengan 33 pertanyaan, dan analisis data demografis dengan IBM SPSS 25 serta analisis PLS-SEM dengan SmartPLS 3.2.8. Hasilnya adalah dari dua belas hipotesis yang diusulkan, tiga hipotesis dinyatakan tidak signifikan dan ditolak karena nilai path coefficient dan t-test dari hipotesis tersebut (performance expectancy, hedonic motivation, dan price value) kurang dari 0,1 dan 1,96, sedangkan sembilan hipotesis lainnya dinyatakan signifikan dan diterima.

Kata Kunci- Penerimaan Pengguna, E-Wallet, UTAUT 2, PLSSEM.

${ }^{1}$ PT. Indonesia Global Solusindo, Tanjung Duren Grogol Petamburan Jakarta Barat 11470 INDONESIA (tlp: +62-21-29501189; e-mail: muhammad.hidayat@is-gs.com)

2,3 Program Studi Sistem Informasi Fakultas Sains dan Teknologi UIN Syarif Hidayatullah Jakarta, Jl. Ir. H. Juanda No. 95 Ciputat Tangerang Selatan 15412 INDONESIA (tlp: +62-21-7401925; email: qurrotul.aini@uinjkt.ac.id,elvi.fetrina@uinjkt.ac.id)

\section{Pendahuluan}

Penggunaan $e$-wallet (dompet elektronik) dalam berbisnis bukan tunai semakin meningkat. Perihal ini disebabkan oleh efektivitas dan efisiensi berbisnis yang disediakan pemberi servis e-wallet [1]. Munculnya e-wallet membantu mempercepat pelanggan/komunitas berhubungan dengan barang dan jasa keuangan. Kebaruan teknologi informasi telah menyebabkan masyarakat melaksanakan aktivitas keuangan di mana pun berada dan kapan saja, dengan tidak sulit, gesit, dan tepercaya [2].

Layanan $e$-wallet berbasis server memerlukan smartphone dan jaringan internet dalam penggunaannya. Hasil riset menunjukkan bahwa pengguna smartphone di Indonesia terus berkembang. Data menyebutkan bahwa dalam lima tahun terakhir, pelanggan smartphone berbasis Android di Indonesia berkembang dari 69,4 juta di tahun 2016 menjadi 86,6 juta tahun 2017 dan 103 juta tahun 2018 [3]. Pertumbuhan yang cepat digerakkan oleh munculnya pelanggan baru tiap tahunnya dan lifestyle berganti smartphone karena mengikuti perkembangan model yang dikeluarkan oleh dealer. Meskipun $e$-wallet berbasis server tergolong baru, dalam penggunaannya telah mengalami peningkatan, yaitu dari tahun 2016 nilai transaksinya sebesar Rp7,06 triliun, meningkat pada 2017 menjadi Rp12,37 triliun, hingga pada 2018 menjadi Rp47,19 triliun [4]. Terhitung sampai Maret 2019, dari catatan Bank Indonesia, sudah ada 36 penerbit yang terdaftar sebagai penerbit $e$-wallet berbasis server. Sebelas penerbit berasal dari perbankan, sedangkan 25 penerbit lainnya adalah dari lembaga nonbank.

Penelitian yang telah dilakukan hasil kerja sama dengan JAKPAT dan OJK menyebutkan bahwa dari tahun 2016 hingga 2018 penggunaan $e$-wallet berbasis server mengalami peningkatan [5]. Terkait e-wallet yang digunakan, dari 825 responden yang menyatakan sebagai pengguna $e$-wallet berbasis server, dengan pengguna terbanyaknya adalah Go-Pay, diikuti OVO, T-Cash (kini menjadi LinkAja), dan yang keempat adalah DANA, seperti ditunjukkan pada Gbr. 1. Namun, dalam penerapannya e-wallet berbasis server masih mengalami permasalahan, di antaranya pengguna mengalami permasalahan berupa hilangnya saldo Go-Pay yang disebabkan oleh gangguan teknis dan sudah melakukan pengisian ulang OVO tetapi saldo pelanggan belum mengalami penambahan [6], [7].

Maraknya penggunaan $e$-wallet berbasis server menyebabkan pentingnya memperoleh nilai keberhasilan penerimaan e-wallet berbasis server [8]. Salah satu faktor penentu keberhasilan sebuah sistem yang diterapkan adalah dari sisi penerimaan, yaitu penggunanya menerima atau 


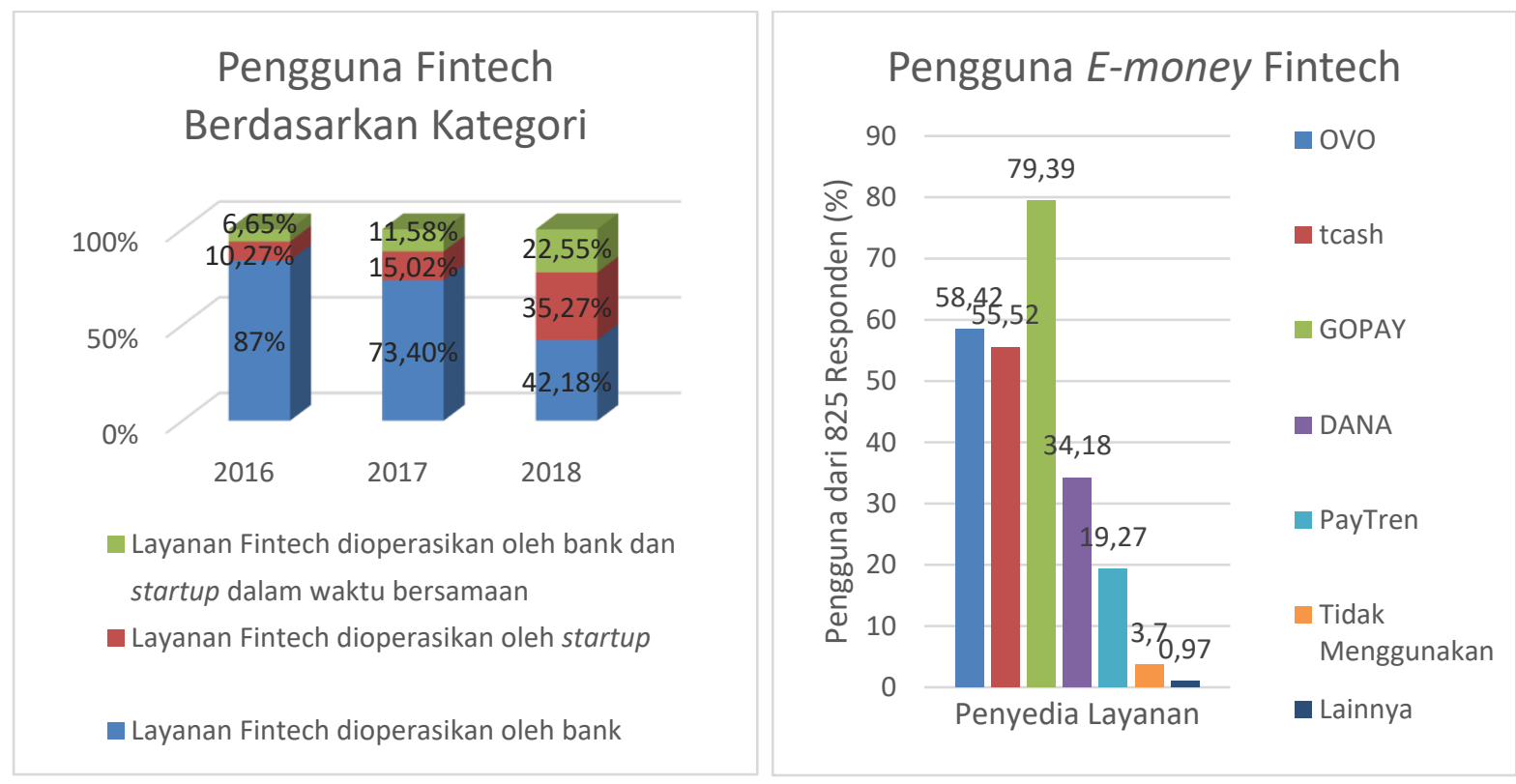

Gbr. 1 Peningkatan pengguna $e$-wallet [5].

menolak menggunakan sebuah sistem baru [9]. Oleh karena itu, makalah ini bertujuan menginvestigasi tingkat penerimaan pengguna $e$-wallet, khususnya Go-Pay, OVO, LinkAja, dan DANA untuk area Tangerang Selatan.

\section{PenerimaAn Pengguna E-Wallet dan UTAUT 2}

\section{A. Konsep Penerimaan Pengguna}

Konsep penerimaan pengguna adalah semakin besar tingkat penerimaan sebuah sistem baru, semakin besar pula keinginan seseorang untuk menggunakan waktu mereka dalam menggunakan sebuah sistem baru [10]. Sedangkan pengertian lain menyatakan bahwa penerimaan pengguna adalah keinginan yang dapat dibuktikan dalam grup pelanggan (customer) yang memfungsikan teknologi informasi yang didesain untuk menunjang aktivitas-aktivitas pelanggannya [11].

Definisi lain menyebutkan bahwa penerimaan pengguna adalah kemauan dari sekelompok orang yang menerapkan teknologi informasi dalam mendukung pekerjaannya. Sedikitnya tingkat penerimaan pelanggan adalah masalah yang esensial bagi keberhasilan implementasi suatu sistem informasi baru. Bahkan pengguna sering tidak mau menggunakan sistem informasi yang telah disediakan, padahal pengguna akan mendapatkan keuntungan jika mau menggunakannya [12]. Oleh karena itu, penerimaan pengguna telah dipandang sebagai salah satu parameter utama dalam menentukan kesuksesan pada suatu proyek sistem informasi.

\section{B. E-Wallet}

Mengacu pada Peraturan Bank Indonesia tahun 2016 nomor 18/40/PBI/2016, e-wallet adalah layanan elektronik untuk menyimpan data instrumen pembayaran, antara lain alat pembayaran dengan menggunakan kartu dan/atau uang elektronik, yang dapat juga menampung dana, untuk melakukan pembayaran [13]. E-wallet adalah implementasi perangkat lunak yang membolehkan pengguna untuk menyimpan uang secara digital, pembayaran digital, dan berbagai jenis transaksi tanpa uang tunai. E-wallet telah digambarkan sebagai cara untuk membayar sesuatu dengan perangkat seperti komputer atau smartphone. E-wallet mampu mengambil fungsi dompet fisik, dengan semua konten dan perilakunya, serta mengintegrasikannya ke dalam perangkat digital [14].

\section{Unified Theory of Acceptance and Use of Technology 2} (UTAUT 2)

(Unified Theory of Acceptance and Use of Technology) UTAUT 2 adalah model penerimaan pengguna yang berpengaruh dan banyak diangkat untuk melaksanakan riset yang berhubungan dengan penerimaan pengguna terhadap suatu teknologi informasi yang lebih berpusat pada konteks konsumen. Model UTAUT 2 dikembangkan pada tahun 2012, terdiri atas tujuh variabel independen, yaitu performance expectancy, effort expectancy, social influence, facilitating conditions, hedonic motivation, price value, dan habit, serta dua variabel dependen, yaitu behavioral intention dan use behavior [15]. Adapun penjelasan masing-masing variabel yang digunakan adalah sebagai berikut [15].

1. Performance expectancy menunjukkan bahwa kepercayaan seseorang pada sebuah $e$-wallet sangat membantu pekerjaan yang dilakukan.

2. Effort expectancy adalah banyaknya usaha untuk menggunakan sebuah $e$-wallet.

3. Social influence menunjukkan bahwa seseorang dapat menggunakan $e$-wallet karena dipengaruhi oleh orang lain.

4. Facilitating conditions menyatakan pengguna dapat yakin bahwa prasarana tersedia dan secara praktik dapat mendukung penggunaan sebuah $e$-wallet.

5. Hedonic motivation merupakan rasa senang yang dirasakan oleh seseorang ketika menggunakan $e$-wallet. 
TABEL I

PENELITIAN YANG MENDUKUNG

\begin{tabular}{|c|c|c|c|c|}
\hline $\begin{array}{c}\text { Domain } \\
\text { Penelitian }\end{array}$ & $\begin{array}{c}\text { Model dan } \\
\text { Tool }\end{array}$ & Variabel & Hasil & Kelebihan dan Kekurangan \\
\hline $\begin{array}{l}\text { E-money di } \\
\text { Indonesia [16] }\end{array}$ & $\begin{array}{l}\text { UTAUT 2, } \\
\text { SmartPLS }\end{array}$ & $\begin{array}{l}\text { Performance expectancy, effort } \\
\text { expectancy, social influence, } \\
\text { facilitating conditions, hedonic } \\
\text { motivation, price value, trust, } \\
\text { perceived technology security, } \\
\text { dan behavioral intention }\end{array}$ & $\begin{array}{l}\text { Terdapat tiga variabel } \\
\text { yang ditolak, yaitu } \\
\text { performance } \\
\text { expectancy, effort } \\
\text { expectancy, dan } \\
\text { perceived technology } \\
\text { security }\end{array}$ & $\begin{array}{l}\text { - Menambahkan dua variabel } \\
\text { yaitu trust,dan perceived } \\
\text { technology security } \\
\text { - Dihilangkan variabel use } \\
\text { behavior }\end{array}$ \\
\hline $\begin{array}{l}\text { E-money di } \\
\text { kecamatan } \\
\text { Ciputat [17] }\end{array}$ & $\begin{array}{l}\text { UTAUT 2, } \\
\text { SmartPLS }\end{array}$ & $\begin{array}{l}\text { Performance expectancy, effort } \\
\text { expectancy, social influence, } \\
\text { facilitating conditions, hedonic } \\
\text { motivation, price value, habit, } \\
\text { behavioral intention, dan use } \\
\text { behavior. }\end{array}$ & $\begin{array}{l}\text { Variabel habit } \\
\text { memberikan pengaruh } \\
\text { terbesar }\end{array}$ & $\begin{array}{l}\text { - Data dan hasil dapat } \\
\text { tergambarkan dengan jelas } \\
\text { - Dihilangkan variabel } \\
\text { moderasi }\end{array}$ \\
\hline $\begin{array}{l}\text { Uang elektronik } \\
\text { di Tangerang } \\
\text { Selatan [18] }\end{array}$ & $\begin{array}{l}\text { UTAUT 2, } \\
\text { SmartPLS }\end{array}$ & $\begin{array}{l}\text { Performance expectancy, effort } \\
\text { expectancy, social influence, } \\
\text { facilitating conditions, hedonic } \\
\text { motivation, price value, habit, } \\
\text { trust, security, behavioral } \\
\text { intention, dan use behavior, serta } \\
\text { tiga variabel moderator (gender, } \\
\text { age, experience) }\end{array}$ & $\begin{array}{l}\text { Semua variabel } \\
\text { berpengaruh signifikan }\end{array}$ & $\begin{array}{l}\text { - Menambahkan dua variabel, } \\
\text { yaitu trust dan security } \\
\text { - Tidak semua variabel } \\
\text { dijelaskan terhadap } \\
\text { interpretasi pada sistemnya }\end{array}$ \\
\hline $\begin{array}{l}\text { Aplikasi food } \\
\text { delivery [19] }\end{array}$ & $\begin{array}{l}\text { UTAUT 2, } \\
\text { SmartPLS }\end{array}$ & $\begin{array}{l}\text { Information quality, performance } \\
\text { expectancy, effort expectancy, } \\
\text { social influence, facilitating } \\
\text { conditions, hedonic motivation, } \\
\text { price value, habit, continuos } \\
\text { intention }\end{array}$ & $\begin{array}{l}\text { Terdapat dua variabel } \\
\text { yang ditolak, yaitu } \\
\text { hedonic motivation, } \\
\text { price value }\end{array}$ & $\begin{array}{l}\text { - Menambahkan variabel } \\
\text { information quality } \\
\text { - Dihilangkan variabel use } \\
\text { behavior }\end{array}$ \\
\hline $\begin{array}{l}\text { Aplikasi mobile } \\
\text { untuk restoran } \\
\text { [20] }\end{array}$ & $\begin{array}{l}\text { UTAUT 2, } \\
\text { SmartPLS }\end{array}$ & $\begin{array}{l}\text { Expectancy, effort expectancy, } \\
\text { social influence, facilitating } \\
\text { conditions, hedonic motivation, } \\
\text { price value, habit, behavioral } \\
\text { intention, dan use behavior }\end{array}$ & $\begin{array}{l}\text { Semua variabel } \\
\text { berpengaruh signifikan }\end{array}$ & $\begin{array}{l}\text { - Data dan hasil dapat } \\
\text { tergambarkan dengan jelas } \\
\text { - Dihilangkan variabel } \\
\text { moderasi }\end{array}$ \\
\hline
\end{tabular}

6. Price value yaitu pengorbanan konsumen terhadap biaya yang dikeluarkan pada $e$-wallet dengan keuntungan yang didapatkan.

7. Habit menunjukkan bahwa seseorang dapat melakukan perilaku menggunakan e-wallet secara otomatis karena telah mempelajari perilaku tersebut.

8. Behavioral intention menyatakan harapan atau keinginan perangai pengguna untuk menerapkan sebuah sistem baru yaitu e-wallet dipengaruhi oleh tindak tanduk pengguna dan disadari kebermanfaatannya oleh orang yang menggunakannya.

9. Use behavior menunjukkan penggunaan diukur dengan frekuensi aktual dalam menggunakan $e$-wallet.

\section{Domain Riset UTAUT 2}

Referensi [16]-[20] menunjukkan rujukan pada penelitian tingkat penerimaan pengguna $e$-wallet berbasis server. Riset sebelumnya yang relevan, terkait, dan mendukung makalah ini berupa hasil, metode, model, tool, variabel, dan domain penelitian ditunjukkan pada Tabel I. Penerapan model UTAUT 2 banyak digunakan pada keberhasilan penerimaan pengguna untuk e-money di beberapa wilayah di Indonesia. Beberapa variabel ditolak seperti performance expectancy, effort expectancy, dan perceived technology security. Eksplorasi lebih lanjut terhadap variabel lain dilakukan untuk mendapatkan nilai signifikansinya. Penerapan UTAUT 2 tidak hanya pada e-money, tetapi pada aplikasi dari sisi penerimaan pengguna, seperti pada aplikasi food delivery dan aplikasi mobile untuk restoran.

Pengukuran keberhasilan penerimaan pengguna dengan menggunakan UTAUT 2 pada e-money dengan menambahkan variabel trust dan security juga telah dilakukan [16], [18], meskipun hasilnya menunjukkan bahwa perceived technology security ditolak [16]. Investigasi dilakukan dari perspektif lain dengan menambahkan variabel perceived trust karena rasa aman merupakan variabel penting ketika melakukan transaksi keuangan secara online. Sedangkan variabel perceived risk juga merupakan faktor penting untuk mendapatkan nilai persepsi pengguna tentang ketidakpastian dan kemungkinan konsekuensi yang tidak diinginkan dari sebuah layanan transaksi keuangan berbasis internet, seperti e-commerce dan $e$ banking.

\section{MetODOLOGI}

Makalah ini menggunakan pendekatan kuantitatif untuk mengukur tingkat penerimaan pengguna dan menguji hipotesis 


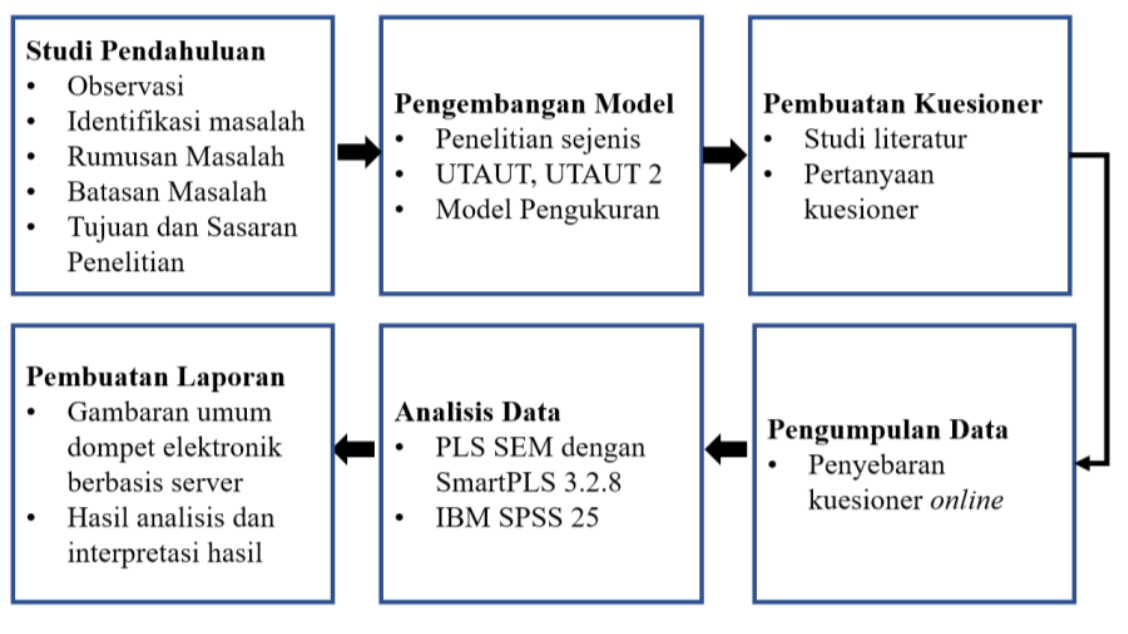

Gbr. 2 Tahapan penelitian.

faktor-faktor yang memengaruhi penerimaan pengguna $e$ wallet berbasis server. Dalam implementasi metode kuantitatif, dibutuhkan cara mengumpulkan data dan menganalisis data dalam mencari solusi riset ini. Koleksi data dilakukan dengan melaksanakan survei dengan kuesioner dan analisis dikerjakan secara statistik menggunakan perangkat lunak pengolah data statistik. Perangkat lunak yang digunakan untuk membantu selama proses penelitian yaitu Microsoft Word 2016 untuk penulisan laporan, IBM SPSS 25 untuk analisis demografis dan Smart-PLS versi 3.2.8 untuk analisis statistik dengan PLS-SEM.

Pengamatan dilaksanakan dengan upaya menilik keadaan, prosedur, dan pemanfaatan $e$-wallet berbasis server di Kota Tangerang Selatan. Observasi dilakukan pada bulan Maret 2019. Survei juga dilakukan dalam membantu proses penelitian menggunakan kuesioner. Proses distribusi kuesioner dilakukan selang dua minggu, mulai tanggal 1-15 Mei 2019. Adapun pengambilan data dilaksanakan dengan mendistribusikan kuesioner secara online melalui media sosial berupa Twitter, Facebook, dan Whatsapp melalui media Google Forms untuk pengisiannya.

\section{A. Populasi dan Sampel Penelitian}

Populasi dari riset ini merupakan pelanggan e-wallet berbasis server di Kota Tangerang Selatan. Pada studi ini, diterapkan metode purposive sampling, dengan menentukan sampel dengan alasan khusus, yaitu pengguna $e$-wallet berbasis server dengan studi kasus Go-Pay, OVO, LinkAja, dan DANA, dengan penentuan ukuran sampel untuk populasi yang tidak diketahui. Mengacu pada penelitian sebelumnya, jumlah sampel minimum studi ini diperoleh menggunakan (1) [21].

$$
n=\left[\frac{Z_{a} / Z_{\sigma}}{e}\right]^{2}=\left[\frac{1,96 / 0,25}{0,05}\right]^{2}=96,04
$$

dengan $n$ adalah jumlah sampel minimum yang diperlukan, $Z_{a}$ adalah tingkat kepercayaan $95 \%(1,96), Z_{\sigma}$ adalah standar deviasi, dan $e$ adalah kesalahan maksimum yang dapat ditoleransi, yaitu sebesar $5 \%$.

Berdasarkan pertimbangan waktu dan biaya, berhasil dikumpulkan sejumlah 162 responden sebagai sampel. Jumlah tersebut dianggap layak sebagai representasi populasi. Hal ini didukung sebuah penelitian yang menyatakan bahwa ukuran sampel minimum pada analisis PLS-SEM adalah sepuluh kali jumlah maksimum anak panah (jalur) yang berkenaan dengan variabel laten [22]. Pada penelitian ini digunakan sebanyak sebelas jalur, sehingga sampel minimum adalah 110. Selain itu, jumlah 162 dianggap cukup karena secara statistik dinyatakan bahwa ukuran sampel yang semakin besar akan memberikan hasil yang semakin baik [23].

\section{B. Tahapan Penelitian}

Makalah ini menggunakan tahapan yang diawali studi pendahuluan, membuat model, mendesain penelitian, mempersiapkan instrumen kuesioner, koleksi data, analisis data, tafsiran data, dan menulis hasil penelitian. Secara spesifik, tahapan penelitian yang digunakan ditunjukkan pada Gbr. 2.

\section{USUlan MODEl DAN PERTANYAAN PENELITIAN}

\section{A. Usulan Model Penelitian}

Studi ini dilaksanakan dengan memperpanjang model UTAUT 2, yaitu mengusulkan bentuk penelitian baru yang sesuai dengan objek penelitian. Construct perceived trust dan perceived risk ditambahkan di sini sesuai dengan permasalahan sistem yang telah ditemukan sebelumnya. Perceived trust, yaitu variabel yang menyatakan rasa aman ketika melakukan transaksi keuangan secara online, penting untuk meminimalkan kekhawatiran tentang penggunaan teknologi saat melakukan pembayaran online [24]. Ada hubungan positif antara tingkat kepercayaan dengan niat penggunaan [25]. Model penelitian ini ditunjukkan pada Gbr. 3.

Adapun penambahan variabel perceived risk dilakukan karena merupakan faktor penting untuk mengetahui persepsi pengguna tentang ketidakpastian dan kemungkinan konsekuensi yang tidak diinginkan dari membeli produk atau layanan, terutama untuk transaksi berbasis internet, seperti $e$-commerce dan e-banking [26]. Sama halnya dengan perceived trust, penelitian menunjukkan bahwa risiko yang dirasakan memengaruhi adopsi teknologi dan menunjukkan bahwa perceived risk dapat menghasilkan kecemasan yang 


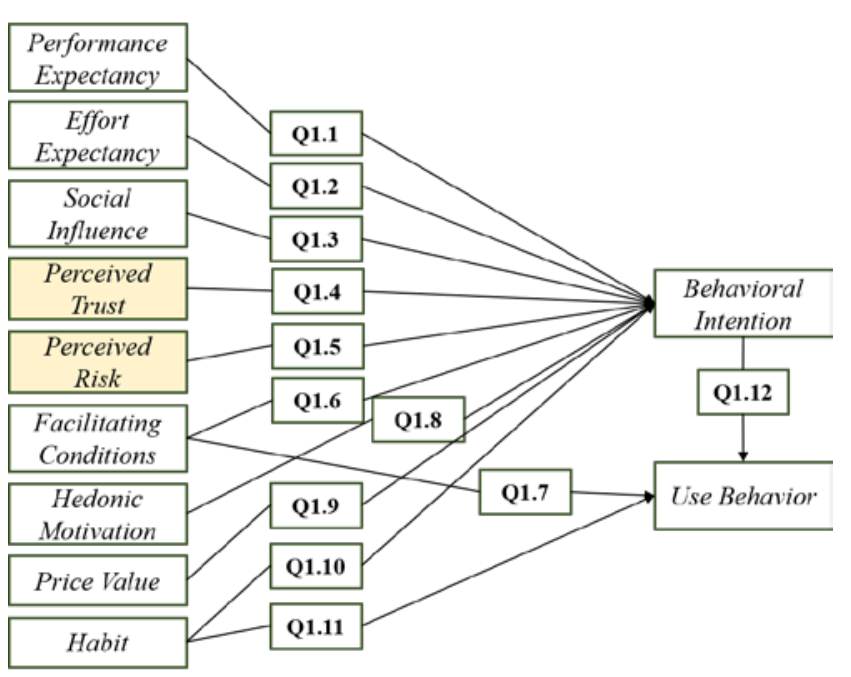

Gbr. 3 Usulan model penelitian.

memengaruhi proses pengambilan keputusan penggunanya [27]. Namun, penelitian ini tidak memasukkan variabel moderator seperti pada model asli UTAUT 2. Tidak digunakannya variabel moderator pada penelitian ini dikarenakan pengamatan serupa yang telah dilakukan menyatakan bahwa sebagian besar penelitian yang menggunakan variabel moderator menunjukkan bahwa variabel moderator akan menurunkan nilai yang dihasilkan [25], [28]. Penelitian lain yang telah dilakukan menunjukkan bahwa tidak ditemukan hubungan yang signifikan pada efek moderasi jenis kelamin dan usia menggunakan model UTAUT pada pengguna mobile banking [29].

\section{B. Pertanyaan Penelitian}

Berdasarkan model penelitian, maka pertanyaan penelitian dalam makalah ini adalah sebagai berikut.

Q1. Apa saja variabel yang menentukan penerimaan pengguna $e$-wallet berbasis server?

Q2. Apakah model penelitian yang digunakan dapat menggambarkan bagaimana penerimaan pengguna $e$ wallet berbasis server?

Q3. Bagaimana tingkat penerimaan pengguna $\boldsymbol{e}$-wallet berbasis server?

Q4. Apakah e-wallet berbasis server yang diterapkan sudah sesuai dengan kebutuhan pengguna?

Selanjutnya, berdasarkan model penelitian yang dipaparkan sebelumnya, berikut adalah variabel yang terkait penerimaan pengguna $e$-wallet berbasis server.

Q1.1 Apakah performance expectancy berpengaruh terhadap behavioral intention?

Q1.2 Apakah effort expectancy berpengaruh terhadap behavioral intention?

Q1.3 Apakah social influence berpengaruh terhadap behavioral intention?

Q1.4 Apakah perceived trust berpengaruh terhadap behavioral intention?

Q1.5 Apakah perceived risk berpengaruh terhadap behavioral intention?
Q1.6 Apakah facilitating conditions berpengaruh terhadap behavioral intention?

Q1.7 Apakah facilitating conditions berpengaruh terhadap use behavior?

Q1.8 Apakah hedonic motivation berpengaruh terhadap behavioral intention?

Q1.9 Apakah price value berpengaruh terhadap behavioral intention?

Q1.10 Apakah habit berpengaruh terhadap behavioral intention?

Q1.11 Apakah habit berpengaruh terhadap use behavior?

Q1.12 Apakah behavioral intention berpengaruh terhadap use behavior?

\section{HASIL ANALISIS}

Survei dilakukan kepada beberapa pengguna yang telah ditentukan sebelumnya berdasarkan kriteria yang dibuat. Survei berupa instrumen penelitian dalam bentuk kuesioner yang didistribusikan secara online dengan alat bantu berupa Google Forms. Sebanyak 162 tanggapan terkumpulkan. Penggunaan Go-Pay menjadi e-wallet berbasis server dengan jumlah tertinggi dan kecamatan di Tangerang Selatan didominasi oleh Ciputat Timur, Ciputat, dan Pamulang. Tabel II merangkum secara detail hasil dari analisis demografi.

Adapun interpretasi Tabel II dapat dijelaskan sebagai berikut. Pengguna e-wallet berbasis server terbesar adalah Go-Pay, seperti yang dirilis tahun 2019 [4]. Khusus untuk kecamatan tempat tinggal di Tangerang Selatan sebagai tempat persebaran kuesioner dilakukan secara online tidak mempertimbangkan distribusi sampel, sehingga diperoleh Kecamatan Ciputat Timur dan Ciputat menjadi mayoritas. Jenis kelamin pengguna $e$-wallet didominasi wanita, sedangkan usia pengguna didominasi usia 17-29 karena distribusi kuesioner dilakukan secara online dengan perantara media sosial yang mayoritas penggunanya adalah kalangan muda. Pada item pendidikan, sebagian besar memiliki latar belakang pendidikan S1. Hal ini terjadi karena persebaran kuesioner dilakukan secara online dengan sasaran rata-rata merupakan mahasiswa S1 dan komunitas yang ada di UIN. Lama penggunaan $e$-wallet mulai satu hingga tiga tahun terakhir dan mayoritas penggunaannya sejak awal beredar. Frekuensi penggunaan $e$-wallet sebagian besar hanya satu hingga tiga kali seminggu, yang mengindikasikan masih rendahnya transaksi yang didasarkan oleh kebutuhan masing-masing pengguna dan belum sepenuhnya dapat menggantikan uang tunai. Nominal pengeluaran dari penggunaan $e$-wallet berbasis server pun masih tergolong rendah. Sedangkan fungsi utama penggunaan masih didominasi pembayaran transportasi online, karena aktivitas pengguna yang menginginkan layanan cepat dan transaksi di perbelanjaan.

Pada tahapan analisis, diukur model outer (outer model), seperti ditunjukkan pada Gbr. 4, dengan beberapa pengujian, yaitu: individual item reliability, internal consistency reliability, average variance extracted, dan discriminant validity. Untuk menguji reliabilitas, dilakukan uji penilaian pada Composite Reliability (CR) dan Average Variance Extracted (AVE). Semua construct yang digunakan sudah memenuhi kriteria dari 
TABEL II

HASIL ANALISIS DEMOGRAFI

\begin{tabular}{|c|c|c|c|}
\hline \multicolumn{2}{|c|}{ Respondents $(n=162)$} & \multirow{2}{*}{$\begin{array}{c}\text { Frekuensi } \\
131\end{array}$} & \multirow{2}{*}{$\begin{array}{c}\begin{array}{c}\text { Persentase } \\
(\%)\end{array} \\
42,4\end{array}$} \\
\hline \multirow{4}{*}{ E-wallet } & GO-PAY & & \\
\hline & OVO & 106 & 34,3 \\
\hline & DANA & 15 & 4,9 \\
\hline & LinkAja & 57 & 18,4 \\
\hline \multirow{7}{*}{$\begin{array}{l}\text { Kecamatan } \\
\text { tempat tinggal }\end{array}$} & Ciputat Timur & 45 & 27,8 \\
\hline & Ciputat & 44 & 27,2 \\
\hline & Pamulang & 43 & 26,5 \\
\hline & Pondok Aren & 15 & 9,3 \\
\hline & Serpong & 12 & 7,4 \\
\hline & Serpong Utara & 2 & 1,2 \\
\hline & Setu & 1 & 0,6 \\
\hline \multirow{2}{*}{ Jenis kelamin } & Wanita & 116 & 71,6 \\
\hline & Pria & 46 & 28,4 \\
\hline \multirow{2}{*}{ Usia } & $17-29$ & 160 & 98,8 \\
\hline & $30-39$ & 2 & 1,2 \\
\hline \multirow{4}{*}{$\begin{array}{l}\text { Pendidikan } \\
\text { responden }\end{array}$} & $\mathrm{S} 1$ & 121 & 74,7 \\
\hline & SMA & 21 & 13,0 \\
\hline & D3 & 15 & 9,3 \\
\hline & $\mathrm{S} 2$ & 5 & 3,1 \\
\hline \multirow{3}{*}{$\begin{array}{l}\text { Lama } \\
\text { penggunaan }\end{array}$} & $\begin{array}{l}1 \text { tahun }-3 \\
\text { tahun }\end{array}$ & 95 & 58,6 \\
\hline & $<1$ tahun & 61 & 37,7 \\
\hline & $\begin{array}{l}3 \text { tahun }-5 \\
\text { tahun }\end{array}$ & 6 & 3,7 \\
\hline \multirow{4}{*}{$\begin{array}{l}\text { Penggunaan } \\
\text { seminggu }\end{array}$} & $1-3$ kali & 88 & 54,3 \\
\hline & $4-6$ kali & 39 & 24,1 \\
\hline & $>10 \mathrm{kali}$ & 26 & 16,0 \\
\hline & $7-10 \mathrm{kali}$ & 9 & 5,6 \\
\hline \multirow{4}{*}{$\begin{array}{l}\text { Nominal } \\
\text { pengeluaran }\end{array}$} & $<\mathrm{Rp} 500.000$ & 148 & 91,4 \\
\hline & $\begin{array}{l}\text { Rp500.000- } \\
\text { Rp1.000.000 }\end{array}$ & 10 & 6,2 \\
\hline & $\begin{array}{l}\text { Rp1.000.000- } \\
\text { Rp2.000.000 }\end{array}$ & 3 & 1,9 \\
\hline & $\begin{array}{l}\text { Rp2.000.000- } \\
\text { Rp3.000.000 }\end{array}$ & 1 & 0,6 \\
\hline \multirow{4}{*}{$\begin{array}{l}\text { Fungsi } \\
\text { penggunaan }\end{array}$} & $\begin{array}{l}\text { Transportasi } \\
\text { online }\end{array}$ & 145 & 41,4 \\
\hline & $\begin{array}{l}\text { Membayar di } \\
\text { toko }\end{array}$ & 88 & 25,1 \\
\hline & Belanja online & 90 & 25,7 \\
\hline & Kirim uang & 27 & 7,7 \\
\hline
\end{tabular}

convergent validity yang baik [28], karena secara keseluruhan nilai dari CR melebihi nilai ambang batasnya yaitu 0,7 [22]. Selain itu, nilai AVE sudah lebih besar dari 0,5 [22]. Tabel III merangkum secara keseluruhan hasil analisis deskriptif tersebut.

Dari hasil analisis yang dilakukan, disimpulkan bahwa pengukuran model ini sudah valid dan reliabel. Karena telah dilakukan evaluasi dan pemeriksaan juga pada nilai akar kuadrat AVE, hasilnya diketahui bahwa masing-masing construct telah memenuhi kriteria discriminant validity.

Secara keseluruhan, dua belas hipotesis yang diusulkan telah diterima pada uji dua sisi dengan tingkat signifikansi $95 \%$. Selanjutnya, dilakukan pengukuran structural model. Tabel IV
TABEL III

CR DAN AVE

\begin{tabular}{|l|l|l|}
\hline \multicolumn{1}{|c|}{ Variabel } & CR & AVE \\
\hline PE & 0,903 & 0,757 \\
\hline EE & 0,916 & 0,784 \\
\hline SI & 0,839 & 0,635 \\
\hline PT & 0,814 & 0,596 \\
\hline PR & 0,845 & 0,646 \\
\hline FC & 0,834 & 0,626 \\
\hline HM & 0,895 & 0,740 \\
\hline PV & 0,889 & 0,727 \\
\hline HT & 0,887 & 0,723 \\
\hline BI & 0,914 & 0,779 \\
\hline UB & 0,834 & 0,626 \\
\hline
\end{tabular}

$\begin{array}{ll}\mathrm{PE}=\text { Performance Expectancy } & \mathrm{HM}=\text { Hedonic Motivation } \\ \mathrm{EE}=\text { Effort Expectancy } & \mathrm{PV}=\text { Price Value } \\ \mathrm{SI}=\text { Social Influence } & \mathrm{HT}=\text { Habit } \\ \mathrm{PT}=\text { Perceived Trust } & \mathrm{BI}=\text { Behavioral Intention } \\ \mathrm{PR}=\text { Perceived Risk } & \mathrm{UB}=\text { Use Behavior } \\ \mathrm{FC}=\text { Facilitating Conditions } & \end{array}$

TABEL IV

KOEFISIEN JALUR DAN VARIABEL

\begin{tabular}{|l|l|l|l|l|l|}
\hline \multicolumn{2}{|c|}{ Hipotetsis } & \multirow{2}{*}{$\boldsymbol{\beta}$} & \multirow{2}{*}{ t-test } & \multicolumn{2}{|c|}{ Analisis } \\
\cline { 1 - 1 } No. & Jalur & & & $\boldsymbol{\beta}$ & T-test \\
\hline Q1.1 & PE $\rightarrow$ BI & 0,035 & 0,488 & IS & R \\
\hline Q1.2 & EE $\rightarrow$ BI & 0,146 & 2,371 & S & A \\
\hline Q1.3 & SI $\rightarrow$ BI & 0,178 & 2,271 & S & A \\
\hline Q1.4 & PT $\rightarrow$ BI & 0,189 & 2,632 & S & A \\
\hline Q1.5 & PR $\rightarrow$ BI & 0,193 & 2,090 & S & A \\
\hline Q1.6 & FC $\rightarrow$ BI & 0,209 & 2,604 & S & A \\
\hline Q1.7 & FC $\rightarrow$ UB & 0,353 & 5,022 & S & A \\
\hline Q1.8 & HM $\rightarrow$ BI & 0,079 & 1,075 & IS & R \\
\hline Q1.9 & PV $\rightarrow$ BI & 0,039 & 0,594 & IS & R \\
\hline Q1.10 & HT $\rightarrow$ BI & 0,297 & 3,965 & S & A \\
\hline Q1.11 & HT $\rightarrow$ UB & 0,212 & 2,756 & S & A \\
\hline Q1.12 & BI $\rightarrow$ UB & 0,156 & 2,026 & S & A \\
\hline
\end{tabular}

$\mathrm{PE}=$ Performance Expectancy $\quad \mathrm{HT}=$ Habit

$\mathrm{EE}=$ Effort Expectancy $\quad \mathrm{BI}=$ Behavioral Intention

$\mathrm{SI}=$ Social Influence $\quad \mathrm{UB}=$ Use Behavior

$\mathrm{PT}=$ Perceived Trust $\quad \mathrm{S}=$ Significant

$\mathrm{PR}=$ Perceived Risk IS = Insignificant

$\mathrm{FC}=$ Facilitating Conditions $\quad \mathrm{A}=$ Accepted

$\mathrm{HM}=$ Hedonic Motivation $\quad \mathrm{R}=$ Rejected

$\mathrm{PV}=$ Price Value

merangkum hasil pengukurannya. Keluaran telaah data pada Tabel IV menunjukkan bahwa effort expectancy, social influence, facilitating conditions, perceived trust, perceived risk, dan habit memiliki hubungan yang signifikan dengan behavioral intention, sedangkan facilitating conditions, habit, dan behavioral intention memiliki hubungan yang signifikan dengan use behavior. Sementara itu, performance expetancy, hedonic motivation, dan price value tidak berpengaruh signifikan terhadap behavioral intention. Relasi variabel yang memiliki efek terbesar pada makalah ini adalah relasi antara facilitating conditions dengan use behavior, dengan nilai path coefficient 0,353 . Sedangkan untuk relasi variabel dengan efek terkecil adalah performance expectancy dengan behavioral intention, dengan nilai path coefficient 0,035 . 


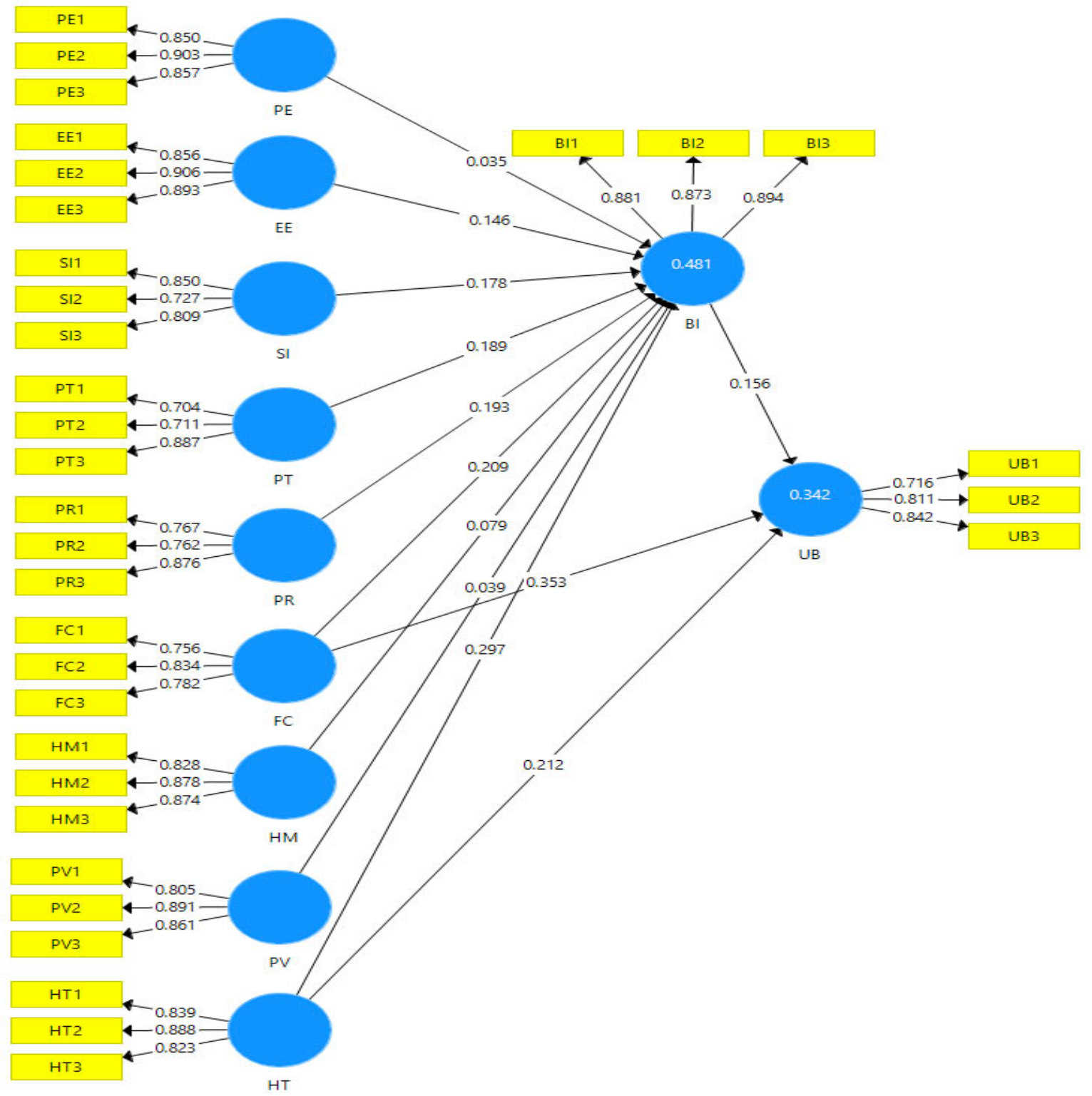

Gbr. 4 Outer model.

\section{DISKUSI}

Beberapa penelitian sebelumnya memiliki kesamaan pengukuran penerimaan teknologi dengan model UTAUT 2 [17], [18]. Referensi [17] menggunakan model UTAUT 2 tanpa menyertakan variabel moderasi, sedangkan [18] menambahkan variabel security dan trust serta variabel moderasi usia (age) dan jenis kelamin (gender). Objek pada kedua penelitian ini adalah e-money berbasis kartu. Bila dibandingkan, pada makalah ini ditambahkan variabel perceived risk dan perceived trust tanpa variabel moderasi dan objek penelitian pada $e$-wallet berbasis server atau aplikasi mobile. E-wallet mencakup GoPay, OVO, LinkAja, dan DANA, yang digunakan dalam berbagai aktivitas transaksi sehari-hari. Adapun kelebihan penelitian dalam makalah ini, selain objek penelitiannya, adalah penambahan variabel perceived trust, yang diperlukan ketika menjalankan bisnis keuangan dengan teknologi online untuk memperkecil kecemasan karena merasa kurang aman tentang pemanfaatan teknologi dalam pembayaran online [24]; dan variabel perceived risk, yang merupakan variabel penting untuk mengetahui persepsi pengguna tentang kebimbangan dan peluang dampak buruk yang tidak diinginkan dari membeli produk atau layanan, terutama untuk transaksi berbasis internet seperti e-commerce dan e-banking [26]. Penghilangan variabel moderasi dilakukan karena pengamatan serupa yang telah dilakukan menyatakan bahwa variabel moderator dapat menjatuhkan nilai yang dihasilkan [15], [28]. Penelitian lain mengungkapkan bahwa tidak ditemukan relasi yang esensial pada efek moderasi jenis kelamin dan usia menggunakan model UTAUT [29].

\section{KESIMPULAN}

Makalah ini menunjukkan bahwa penambahan dua variabel, yaitu perceived trust dan perceived risk berpengaruh signifikan 
terhadap behavioral intention karena mengacu pada uji T-test, jalur tersebut diterima, dan mengacu pada uji path coefficient $(\beta)$, hal tersebut memiliki dampak yang berarti. Ini terjadi karena pihak penyedia layanan $e$-wallet berbasis server bertanggung jawab terhadap permasalahan kehilangan saldo dan gagalnya pengisian saldo, sehingga pengguna merasa percaya dan yakin tidak akan terkena masalah terkait saldo.

Kemudian terkait penggunaan, e-wallet berbasis server didominasi oleh pengguna Go-Pay sebanyak 42,39\%, pengguna perempuan sebanyak $71,60 \%$, penggunaan seminggu dalam 1-3 kali sebanyak 37,65\%, nominal yang dikeluarkan < Rp500.000,00 sebanyak 91,36\%, dan fungsi penggunaan transportasi online sebanyak 41,43\%. Dapat disimpulkan bahwa tingkat intensitas penggunaan masih rendah dan fungsi penggunaan untuk membayar layanan transportasi online menggunakan Go-Pay.

Hasil temuan menunjukkan bahwa effort expectancy, social influence, facilitating conditions, perceived trust, perceived risk, dan habit memiliki hubungan yang signifikan dengan behavioral intention, sedangkan facilitating conditions, habit, dan behavioral intention memiliki hubungan yang signifikan dengan use behavior. Di sisi lain, performance expetancy, hedonic motivation, dan price value tidak berpengaruh signifikan terhadap behavioral intention. Relasi variabel yang memiliki efek terbesar adalah relasi antara facilitating conditions dengan use behavior, dengan nilai path coefficient 0,353 . Sedangkan hubungan variabel dengan pengaruh terkecil adalah performance expectancy dengan behavioral intention, dengan nilai path coefficient 0,035. Temuan ini dapat menjadi pertimbangan praktis bagi penyedia layanan $e$-wallet berbasis server dalam memperbaiki ataupun mengembangkan layanan $e$-wallet berbasis server nantinya. Temuan di sini tidak dapat digeneralisasi dengan temuan penelitian lain karena adanya perbedaan objek penelitian dan teknik pemilihan sampel.

Model penelitian dapat dikembangkan dengan menambahkan variabel kepuasan pengguna (user satiscation) yang dapat berdampak pada niat penggunaan (behavioral intention) dan tingkat intensitas penggunaan (use behavior) $e$-wallet berbasis server. Juga dapat dilakukan pengukuran menggunakan model lain seperti Technology Acceptance Model 2 (TAM 2) dan Technology Acceptance Model 3 (TAM 3).

\section{REFERENSI}

[1] T.D. Isna (2019) "6 Manfaat Dompet Digital bagi Keuangan Anda," [Online], https://www.wartaekonomi.co.id/read211053/6-manfaatdompet-digital-bagi-keuangan-anda, tanggal akses: 24-Jun-2020.

[2] N. Riswari, E. Nugroho, dan A.E. Permanasari, "Evaluasi Sistem Informasi Manajemen Kepegawaian di BKD DIY dengan Metode HOT FIT,” M.T. Tesis, Universitas Gadjah Mada, Yogyakarta, Indonesia, 2015.

[3] E. Purwanto (2019) "2018: Pengguna Smartphone Indonesia Tembus 103 Juta Orang," [Online], https://www.ayooberita.com/berita-----2018pengguna-smartphone-indonesia-tembus-103-juta-orang, tanggal akses: 24-Jun-2020.

[4] A. Septiasi dan W.T. Rahmawati (2019) "Fintech merajai uang elektronik berbasis server, bank hanya 0,2\%," [Online], https://keuangan.kontan.co.id/news/fintech-merajai-uang-elektronikberbasis-server-bank-hanya-02, tanggal akses: 24-Jun-2020.

[5] R. Eka (2018) "Fintech Report 2018," [Online], https://dailysocial.id/report/post/fintech-report-2018, tanggal akses: 24Jun-2020.
[6] Y.Y. Fauzie (2017) "Gojek Angkat Bicara Terkait Saldo Gopay yang Hilang,"

[Online],

https:/www.cnnindonesia.com/teknologi/20170928093003-185244535/gojek-angkat-bicara-terkait-saldo-gopay-yang-hilang, tanggal akses: 24-Jun-2020.

[7] A.S. Wardani (2019) "Ramai Pengguna Gojek Keluhkan Isi Ulang Gopay Tak Masuk ke Saldo," [Online], https://www.liputan6.com/tekno/read/3922630/ramai-pengguna-gojekkeluhkan-isi-ulang-gopay-tak-masuk-ke-saldo, tanggal akses: 24-Jun2020.

[8] P.H. Adi, "Partisipasi Pengguna Dalam Pengembangan Sistem Informasi (Telaah Literatur),” Jurnal Akuntansi dan Keuangan, Vol. 8, No. 1, hal. 52-61, Mei 2006.

[9] J. Ouadahi, “A Qualitative Analysis of Factors Associated with User Acceptance and Rejection of a New Workplace Information System in the Public Sector: A Conceptual Model," Canadian Journal of Administrative Sciences, Vol. 25, No. 3, hal. 201-213, Agt. 2008.

[10] N.Z. Hosein, "Internet Banking: An Empirical Study of Adoption Rates among Midwest Community Banks," Journal of Business \& Economics Research, Vol. 7, No. 11, hal. 51-72, Nov. 2009.

[11] F.D. Davis, "User Acceptance of Information Technology: System Characteristics, User Perceptions and Behavioral Impacts,” International Journal of Man-Machine Studies, Vol. 38, No. 3, hal. 475-487, Mar. 1993.

[12] A. Dillon dan M.G. Morris, "User Acceptance of New Information Technology: Theories and Models," dalam Annual Review of Information Science and Technology, Vol. 31, M. Williams, Ed. Medford, USA: Information Today, 1996, hal. 3-32.

[13] (2016) "Peraturan Bank Indonesia No. 18/40/PBI/2016 tentang Penyelenggaraan Pemrosesan Transaksi Pembayaran,” [Online], https://www.bi.go.id/id/peraturan/sistempembayaran/Pages/pbi_184016.aspx, tanggal akses: 24-Jun-2020.

[14] J. Lanier, You Are Not a Gadget: A Manifesto. New York, USA: Alfred A. Knopf, 2010.

[15] V. Venkatesh, J.Y.L. Thong, dan X. Xu, “Consumer Acceptance and Use of Information Technology: Extending the Unified Theory of Acceptance and Use of Technology,” MIS Quarterly, Vol. 36, No. 1, hal. 157-178, Mar. 2012.

[16] N. Diana, “Analisis Faktor-Faktor yang Memengaruhi Minat Penggunaan Electronic Money di Indonesia,” S.E. skripsi, Universitas Islam Indonesia, Yogyakarta, Indonesia, 2018.

[17] M.A.A. Putra, "Evaluasi Penggunaan pada Produk Uang Elektronik EMoney Bank Mandiri Menggunakan Model UTAUT 2 (Studi Kasus: Kecamatan Ciputat)," S.Kom Skripsi, Universitas Islam Negeri Syarif Hidayatullah, Jakarta, Indonesia, 2018.

[18] D.R. Sabarkhah, “Pengukuran Tingkat Penerimaan dan Penggunaan Teknologi Uang Elektronik di Tangerang Selatan dengan Menggunakan Model UTAUT 2,” S.Kom. Skripsi, Universitas Islam Negeri Syarif Hidayatullah, Jakarta, Indonesia, 2018.

[19] S.W. Lee, H.J. Sung, dan H.M Jeon, "Determinants of Continuous Intention on Food Delivery Apps: Extending UTAUT2 with Information Quality,” Sustainability, Vol. 11, No. 11, hal. 1-15, Jun. 2019.

[20] R.P. Saumell, S.F. Coll, J.S. García, dan E. Robres, "User Acceptance of MobileApps for Restaurants: An Expanded and Extended UTAUT-2,” Sustainability, Vol. 11, No. 4, hal. 1-24, Feb. 2019.

[21] Riduwan dan Akdon, Rumus dan Data Dalam Analisis Statistika. Bandung, Indonesia: Alfabeta, 2013.

[22] J.F. Hair, W.C. Black, B.J. Babin, dan R.E. Anderson, Multivariate Data Analysis, 6 ${ }^{\text {th }}$ ed., New Jersey, USA: Prentice Hall, 2010.

[23] I. Alwi, "Kriteria Empirik dalam Menentukan Ukuran Sampel pada Pengujian Hipotesis Statistika dan Analisis Butir," Formatif: Jurnal Ilmiah Pendidikan MIPA, Vol. 2, No. 2, hal. 140-148, 2012.

[24] W. Salisbury, R. Pearson, A. Pearson, dan D. Miller, "Perceived Security and World Wide Web Purchase Intention,” Industrial Management \& Data Systems, Vol. 101, No. 4, hal. 165-177, 2001.

[25] B. Suh dan I. Han, "Effect of Trust on Customer Acceptance of Internet Banking,” Electronic Commerce Research and Applications, Vol. 1, No. 3-4, hal. 247-263, 2002.

[26] D. Littler dan D. Melanthiou, “Consumer Perceptions of Risk and 
Uncertainty and The Implications for Behaviour Towards Innovative Retail Services: The case of Internet Banking,” J. Retail. Consum. Serv., Vol. 13, No. 6, hal. 431-443, Nov. 2006.

[27] J.W. Taylor, "The Role of Risk in Consumer Behavior," Journal of Marketing, Vol. 38, No. 2, hal. 54-60, April 1974.

[28] Y.K. Dwivedi, N.P. Rana, A. Jeyaraj, M. Clement, dan M.D. Williams, "Re-examining the Unified Theory of Acceptance and Use of Technology
(UTAUT): Towards a Revised Theoretical Model,” Information System Frontiers, Vol. 21, No. 3, hal. 719-734, 2019.

[29] T. Oliveira, M. Faria, M.A. Thomas, dan A. Popovič, "Extending the Understanding of Mobile Banking Adoption: When UTAUT Meets TTF and ITM,” International Journal of Information Management, Vol. 34, No. 15, hal. 689-703, Okt. 2014. 